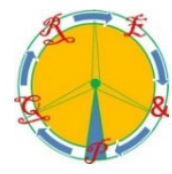

\title{
Solar Energy as an alternative source in boiler economizers
}

\author{
A. Daniel Pereira de Oliveira1, B. Aylton José Alves1, C. Bárbara Morais Arantes2 \\ 1. Pós-Graduação em Tecnologia de Processos Sustentáveis, Instituto Federal de Goiás, Goiânia, Brasil, phone: \\ +55062981231123, e-mail: A. daniel@powerplant.com.br, B. aylton.alves@ifg.edu.br
}

\begin{abstract}
2Pós-Graduação em Ciências da Saúde, Universidade Federal de Goiás, Goiânia, Brasil, phone: +55062981231123, e-mail: C.barbaraufg@yahoo.com.br
\end{abstract}

\begin{abstract}
This study sought to analyze the viability of the use of solar energy, for the operation in boiler economizers, in the replacement of the thermal energy of the exhaust gases. The experiment was divided in two steps: analysis of the boiler yield with different feed water temperatures and addition of the solar field to the initial set. For the modeling of the economizer-boiler set, the software used was Engineering Equation Solver (Software F-Chart, Wisconsin, USA). The technology chosen for the second stage was the high-pressure vacuum solar collector, installed at the inlet of the feed water heater. The thermal power of $2014 \mathrm{~W}$ (per plate) and the solar radiation peak of $1000 \mathrm{~W} / \mathrm{m}^{2}$ were standardized, taking into account the calculations for a steady state system at noon. The variable was the number of solar panels to be used at the plant. After analyzing the data, it was verified that the efficiency varied by approximately $7.4 \%$, when the feed water temperature was increased by $20^{\circ} \mathrm{C}$, close to $48^{\circ} \mathrm{C}$. In order for this variation to occur, it was necessary to use 50 plates.
\end{abstract}

Key words. Boiler, Economizer, Solar Energy.

\section{Introduction}

Since the beginning of the 19th century, as a result of the Industrial Revolution, steam has been used on a large scale in the processing industries as a working fluid in thermal machines. Many researches have been developed in the engineering area to develop new technologies to reduce the energy consumption of these machines, in addition to improving processes, reducing operating costs, sustaining the production chain and reducing environmental impact $[1,2,3]$.

In the universe of thermal machines, boilers play a prominent role, being considered the heart of modern industries, in which the cost of fuel represents a considerable part of the system's performance.

Considering the case of industrial steam generation, for heating, sterilization and humidification purposes (saturated steam), several sources of fuel are used today, among them: coal, bagasse, petroleum products, coke, natural gas, wood in general, rice straw, among others. Among these, it is important to highlight the coal-fired industrial plants, one of the most used fuels in the world for the production of steam in thermoelectric plants, in the sectors of steel, pulp and paper, cement industry, among others $[4,5]$.
Despite the market importance of the coal-fired industrial units, it is worth noting that there is a high environmental cost, among which can be highlight [5].

Process of cleaning flue gases with heavy water, which can contaminate as water basins and consequently affect the environmental balance; With the burning of coal there are emissions of gases and particulate pollutants such as: carbon monoxide, carbon dioxide, sulfur dioxide and nitrous oxide. Contamination of the soil is potentially harmful to agriculture and to the health of living beings who depend on it. These pollutants, which are loaded with gases, contaminate the soil and are especially harmful to agriculture and human health. Another direct consequence is the greenhouse effect from the production of carbon dioxide;

Some measures to reduce pollutants from coal burning can be taken, such as the implementation of carbon capture and storage technologies, which in turn reduces efficiency and increases the costs of industrial plants and power generation plants [6]. This demonstrates that other techniques of consumption reduction are necessary.

In this sense, economizer modules were developed, which coupled to the boiler system, increase the efficiency and reduce the amount of fuel used. The economizers have the function of raising the temperature of the feed water, thus allowing the conservation of thermal energy of the system, in addition to increasing the useful life of the equipment [7].

One factor that has great influence in the generation of energy is the reduction and the rational use of the fuels. The reduction in the use of fossil fuels such as coal, oil and oilderived gases is sought, to the detriment of the use of renewable technologies and fuels, or the combined cycle use of two or more types of energy sources. In the near future, the goal is to use a matrix increasingly based on renewable sources of energy [11].

The improvement of energy engineering influences these scenarios in the sense of developing alternatives that are beneficial to the environment. This includes improvements 
in existing processes, promoting changes in the productive sector, improving the technology and science of materials, processes, equipment and fuels, with the objective of producing energy efficiently, regardless of the method used [13].

A major challenge, involving energy efficiency in boilers, is the high cost of adapting machines to implement economizers, as they are available in the market. Based on the assumptions presented, which include boilers being the most used devices in the industry, and that these demand a high energy supply, the search for alternatives of increase of efficiency, based on renewable energies, is the main impetus of this study. Thus, it sought to analyze the viability of the use of solar energy, for the operation of economizers in boilers, in the substitution of thermal energy, from the exhaust gases. This was developed, based on the Brazilian territorial reality, which has a high potential of solar energy supply.

\section{A. Theoretical Conception}

The Brazilian Atlas of Solar Energy was published in 2006, and was elaborated under the scope of the Solar and Wind Energy Resource Assessment (SWERA), under the guidance of the National Institute of Space Research (INPE). In this, the map of direct annual irradiation for Brazil was presented, highlighting important solarimetric indexes for the regions of the valley of the São Francisco river in Bahia and on the border between the states of São Paulo, Paraná and Mato Grosso do Sul [14].

Figure 1 presents Brazil with the annual accumulation of direct solar irradiation, where the darkest regions have the lowest index and the lightest ones, with indices varying from 2.000 to $2.400 \mathrm{kWh} / \mathrm{m}^{2} /$ year [14].

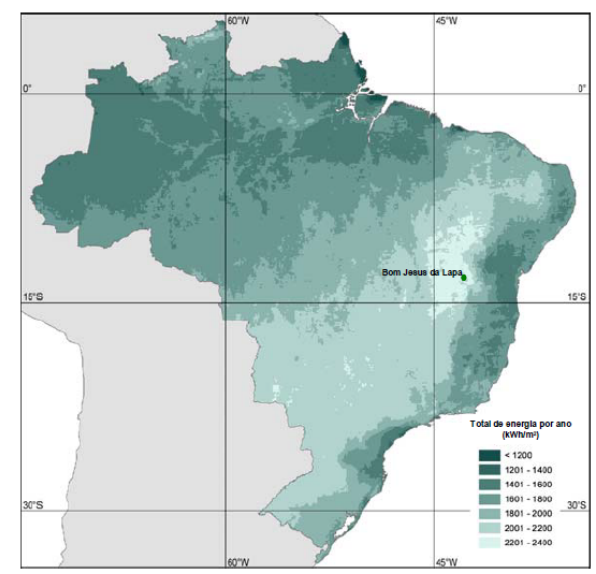

Fig 1. Accumulated annual direct solar irradiation (BRASIL, 2012).

The map also shows that global irradiation is well distributed among the regions of Brazil, with an annual average irradiance ranging from 1.200 to $2.400 \mathrm{kWh} / \mathrm{m}^{2} /$ year, significantly higher than the average of most countries in Europe. Germany, 900 to $1.650 \mathrm{kWh} / \mathrm{m}^{2} /$ year in France and 1.200 to $1.850 \mathrm{kWh} / \mathrm{m}^{2} /$ year in Spain.

The power cycle of solar thermal plants has the same principle of operation of conventional plants, capturing solar irradiation and redirecting thermal energy for the heating of a specific fluid, besides the use of steam to drive turbines and generators. Brazil has technological dominance in thermodynamic conversions and thermoelectric cycles.

In general, solar-thermal processes are still developing in the world. The countries that use most of this technology are the United States and Spain, mainly because they have interesting indexes of solar irradiation and policies of incentives of the use of these energies [12].

It is true that Brazil has investments to use solar energy, increasing energy in processes that help reduce the use of fossil fuels, contributing to environmental sustainability.

Boilers represent the most important device in the field of thermal machines, which are special machines, which have the function of converting heat into work and its main characteristics are that [7]:

- They work with high temperature heat sources (solar energy, combustion chamber, reactors, etc.)

- Convert heat into work

- Have the cycle operation

Steam boilers are equipment that uses the chemical energy released in the combustion process of a given fuel, promoting the phase change of water from the liquid state to the vapor state.

This transformation usually occurs in a pressure range several times above atmospheric pressure. The steam produced is then used for heating and sterilization purposes in industrial processes and for generating mechanical and electrical power in the drive of thermal machines.

The boilers have two main elements, which are the combustion chamber, where the fuel burns and the exchange surfaces, where heat exchanges of the working fluid are carried out with the hot gases.

The efficiency of a boiler is the ratio of the energy transferred to the water to convert it to steam and the consumption of the intrinsic energy of the fuel [8].

The calculation of this yield corresponds to the product of the mass vapor flow and the enthalpy change between the initial and final stages of the water, divided by the thermal energy that is released through the consumption of the fuel, according to Eq. (1):

$$
\eta=\frac{m v \cdot(h v-h a)}{m c \cdot P C}
$$

Onde:

$\eta=$ thermal efficiency

$m v=$ mass flow of steam $(\mathrm{kg} / \mathrm{s})$

$h v=$ enthalpy of steam produced by the boiler $(\mathrm{kJ} / \mathrm{kg})$

$h a=$ enthalpy of feed water to the boiler $(\mathrm{kJ} / \mathrm{kg})$

$m c=$ mass flow of fuel $(\mathrm{kg} / \mathrm{s})$ 


$$
P C=\text { calorific value of fuel }(\mathrm{kJ} / \mathrm{kg})
$$

Figure 2 shows a basic boiler plant without economizer, where: (VS) saturated steam; (AA) heating or power water; (t1) heating water temperature ( $\mathrm{t} 2)$ saturated steam temperature.

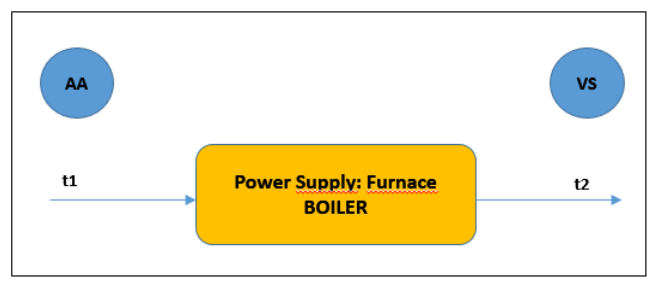

Fig. 2. Simulator plant without economizer

Table I shows the average cost of producing a ton of steam from the use of charcoal used in this study and the cost for other energy sources [15].

Table I - It exemplifies the average cost of producing a tonne of steam from charcoal and other sources of energy

\begin{tabular}{ccccc}
\hline $\begin{array}{c}\text { Oil } \\
\text { LFP }\end{array}$ & $\begin{array}{c}\text { Natural } \\
\text { Gás }\end{array}$ & $\begin{array}{c}\text { Electrical } \\
\text { resistance }\end{array}$ & Charcoal & Mineral Coal \\
\hline USD 36,23 & USD 23,49 & USD 54,22 & USD 11.15 & USD 6,75 \\
\hline
\end{tabular}

(ARMATUREN, 2019)

\section{Methodology}

The experiment was divided into two stages:

1. Analysis of boiler efficiency, with different temperatures of feed water

2. Addition of the solar field to the initial set, followed by calculation and modeling of the solar energy system, to reach the heating of the water for a final yield close to $5 \%$, parameter verified for the current gas economizers used in the boilers of greater Yield [9].

It was decided to use measurement units most commonly adopted in industrial thermal systems in the Brazilian territory. Therefore, calculations and technical descriptions are presented in such units of measurement, which are not always equivalent to the units of the international system. The process data and solar collector data are described in table II.

Table II - Process data and Solar Collector Data.

\begin{tabular}{ll}
\hline \multicolumn{2}{c}{ Process data } \\
\hline Intended efficiency in the system & $5-7 \%$ \\
\hline Lower calorific value of fuel (charcoal) & $7.500 \mathrm{kCal} / \mathrm{kg}$ \\
\hline Feed water temperature & $28^{\circ} \mathrm{C}$ \\
\hline Saturated steam temperature & $120^{\circ} \mathrm{C}$ \\
\hline Boiler inlet pressure & $15.900 \mathrm{kPa}$ \\
\hline Boiler outlet pressure & $15.200 \mathrm{kPa}$ \\
\hline Boiler working flow (steam flow) & $10 \mathrm{~m}^{3} / \mathrm{h}$ \\
\hline
\end{tabular}

Solar Collector Data

\begin{tabular}{ll}
\hline $\begin{array}{l}\text { Dimensions } \\
(\mathrm{LxWxH})\end{array}$ & $\begin{array}{l}2005 \mathrm{~mm} \times 2196 \mathrm{~mm} \times \\
136 \mathrm{~mm}\end{array}$ \\
\hline Peak output & $2014 \mathrm{~W}$ \\
\hline Material & borosilicato 3.3 \\
\hline Flow rate & máx. $15 \mathrm{~L} / \mathrm{min}$ \\
\hline $\begin{array}{l}\text { Peak solar radiation } \\
\text { collector (12:00PM) }\end{array}$ & the \\
\hline Absorptance & $1000 \mathrm{~W} / \mathrm{m}^{2}$ \\
\hline Emittance & $>93 \%(\mathrm{AM} 1.5) ;$ \\
\hline Vacuum & $<8 \%\left(80^{\circ} \mathrm{C}\right)$ \\
\hline Startup temperatura & $\mathrm{P}<5 \times 10-{ }^{3} \mathrm{~Pa}$ \\
\hline Operating angle & $>30^{\circ} \mathrm{C}$ \\
\hline Max operating pressure & $20-80^{\circ}$ \\
\hline Pipe composition & $800 \mathrm{kPa} / 8 \mathrm{bar}$ \\
\hline Manufacturer & $\begin{array}{l}\text { High purity oxygen free } \\
\text { copper }(\mathrm{ASTM}: \mathrm{C} 10200 ; \\
\mathrm{DIN}: \mathrm{OF}-\mathrm{Cu})\end{array}$ \\
\hline
\end{tabular}

Below are some illustrative ETC figures:

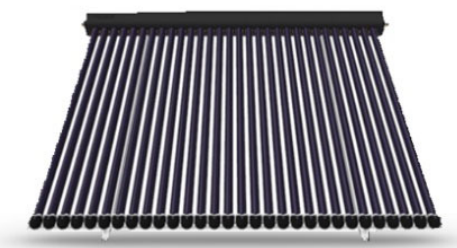

Fig. 3. Front View of ETC

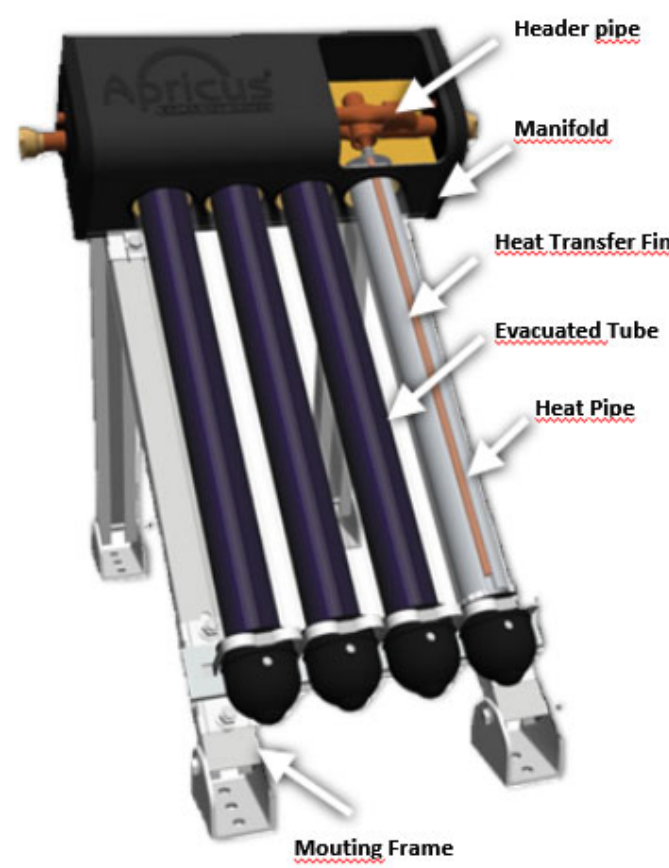

Fig. 4. ETC Components 


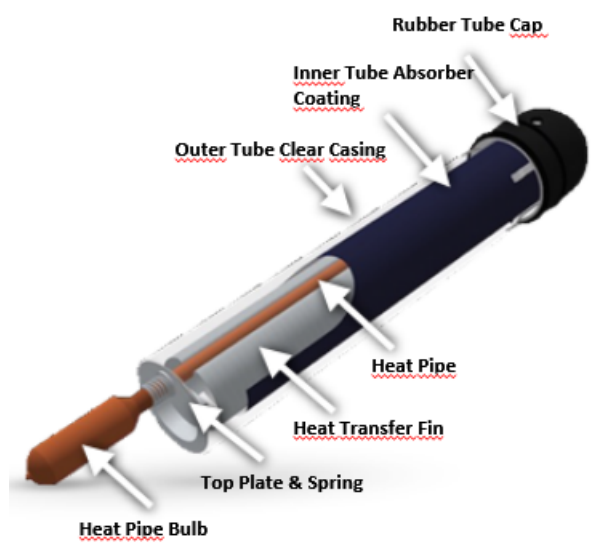

Fig. 5. Evacuated Tube \& Heat Pipe

For the economizer-boiler set modeling, the software used was the Engineering Equation Solver (F-Chart Software, Wisconsin, USA). The simulator variable was the feedwater temperature. The calculation of the thermal machine's performance was performed with steps of variation of the temperature of the feeding water, varying from $28^{\circ} \mathrm{C}$ to $58^{\circ} \mathrm{C}$ with an upward step of $10^{\circ} \mathrm{C}$. A flow rate of $10 \mathrm{~m}^{3} / \mathrm{h}$ was standardized for the feed water and $120^{\circ} \mathrm{C}$ the temperature of the steam generated by the boiler. This steam temperature corresponds to that used in sterilization and cooking processes in industries in general.

This type of steam was chosen because it is used in the vast majority of basic industries, except for thermoelectric plants. The fuel used in this simulator was charcoal, whose lower calorific value (LCV) is $7,500 \mathrm{kCal} / \mathrm{kg}$. For the boiler inlet pressure was adopted the value of $15,900 \mathrm{kPa}$ and the outlet pressure as $15,200 \mathrm{kPa}$, considering the system losses. For enthalpy and entropy values the International Association for Water and Steam (IAPWS) standardized values, previously loaded in the EES software, were used through the Steam IAWPS function, which implements high precision thermodynamic properties for steam and steam calculations. providing accurate results for temperatures between $273.15 \mathrm{~K}$ and $1273.15 \mathrm{~K}$ and pressures up to $1000 \mathrm{MPa}$.

After analyzing the technologies available for industrial level heating purposes, it was decided to use in this experiment, due to the low cost, ease of installation, acquisition and satisfactory efficiency, the High Pressure Vacuum Solar Collector, or Pipe Collector. Evacuated (ETC), which provides $2014 \mathrm{~W}$ thermal power per plate, data provided by the manufacturer for peak solar radiation of $1000 \mathrm{~W} / \mathrm{m}^{2}$ at noon (12:00 PM).

In addition, to calculate the solar field output power, the IAM (Incidence Angle Modifier) parameter was considered in order to obtain the actual output power of the system, taking into account the correction factor due to solar incidence angle, which varies throughout the day on the plate set, as shown in the table below.
Table II - Incidence angle modifier

\begin{tabular}{ccccccccc}
\hline Angle & $\mathbf{0}^{\circ}$ & $\mathbf{1 0}^{\circ}$ & $\mathbf{2 0}^{\circ}$ & $\mathbf{3 0}^{\circ}$ & $\mathbf{4 0}^{\circ}$ & $\mathbf{5 0}^{\circ}$ & $\mathbf{6 0}^{\circ}$ & $\mathbf{7 0}^{\circ}$ \\
\hline Longitudinal & 1 & 1 & 1 & 0.99 & 0.98 & 0.97 & 0.94 & 0.88 \\
\hline Transverse & 1 & 1.03 & 1.07 & 1.16 & 1.31 & 1.4 & 1.44 & 1.3 \\
\hline
\end{tabular}

Considering then the calculations for a steady state system in equilibrium at the moment analyzed. This system was installed in modeling at the inlet of the feed water heater. As a result, the number of solar plates to be used in the plant was generated.

\section{Results}

\section{A. Step 1 - Test of the boiler efficiency with the raising of the temperature of the feed water}

For the equation (1), the system composed only of the boiler was considered, and the yield was calculated for different feed water temperatures, in order to verify the increment of yield, from the elevation of the water temperature boiler power supply.

When the feed water temperature was varied from $28^{\circ} \mathrm{C}$ to $58^{\circ} \mathrm{C}$ in steps of $10^{\circ} \mathrm{C}$, the results shown in Table II were obtained. Standardized data for the calculation: $\mathrm{P} 1=15.900$ $\mathrm{kPa} ; \mathrm{P} 2=15.200 \mathrm{kPa} ; \mathrm{mv}(\mathrm{kg} / \mathrm{sec})=2,77 ; \mathrm{mc}(\mathrm{kg} / \mathrm{sec})=$ 0,$1 ; \mathrm{PC}=31.380 ; \mathrm{s} 2=1,515$

Table III - Result of the yields according to the variation of the boiler feed water temperature.

\begin{tabular}{|c|c|c|c|c|c|c|c|c|}
\hline $\begin{array}{c}\text { t1 } \\
\left({ }^{\circ} \mathrm{C}\right)\end{array}$ & $\begin{array}{c}\text { t2 } \\
\left({ }^{\circ} \mathrm{C}\right)\end{array}$ & h1 & h2 & s1 & s2 & EFGV & $\begin{array}{c}\text { EFGV } \\
(\%)\end{array}$ & $\begin{array}{c}\text { INC } \\
\eta \\
(\%)\end{array}$ \\
\hline 28 & 120 & 131,9 & 514,4 & 0,4044 & 1,515 & 0,3377 & 33,77 & - \\
\hline 38 & 120 & 173,3 & 514,4 & 0,5397 & 1,515 & 0,3011 & 30,11 & 3,66 \\
\hline 48 & 120 & 214,7 & 514,4 & 0,6707 & 1,515 & 0,2646 & 26,46 & 7,31 \\
\hline 58 & 120 & 256,2 & 514,4 & 0,7979 & 1,515 & 0,2279 & 22,79 & 10,98 \\
\hline
\end{tabular}

t1) heating water temperature; t2) saturated vapor temperature; mc) fuel mass flow rate $(\mathrm{kg} / \mathrm{s}) ; \mathrm{mv})$ mass flow rate of steam $(\mathrm{kg} / \mathrm{s})$; PC) calorific value of fuel ( $\mathrm{kJ} / \mathrm{kg})$; P1) boiler inlet pressure; P2) boiler outlet pressure; h1) enthalpy 1 ; h2) enthalpy 2; s1) entropy 1 ; s2) entropy 2; EFGV) efficiency of the steam generator (boiler); INC.) Yield increase.

From the data in Table II, it was observed that, in order to achieve the desired efficiency of approximately $7 \%$, it was necessary to raise the feed water temperature by $20^{\circ} \mathrm{C}$.

After this, the study proceeded with the second stage of the experiment, in order to verify the amount of plates needed for the solar field, would be used to produce the same effect of raising the feed water temperature to the system at $20^{\circ} \mathrm{C}$

B. Step 2-Test of the boiler efficiency with the elevation of the temperature of the feed water trough the solar field

Figure 6 illustrates the schemas used for the studies of Step 2 . At this stage the same system and the same temperature variations in the feed water, developed in step 1 , were added, adding the solar field, which in this case will be 
responsible to produce the feed water temperature increments.

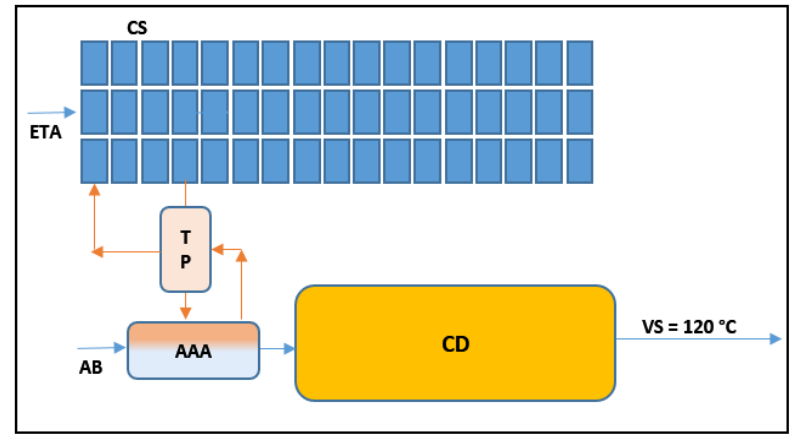

Fig. 6. Plant with solar field addition.

In Figure 6, (CS) solar field; (ETA) source of cold water; (TP) lung tank with heated water; (AB) raw water supply, (AAA) feed water heater element, which provides a supply fluid with variable temperature; (CD) boiler, (VS) saturated steam.

A set of plates with high pressure (CS) collector tubes was used, with the objective of achieving a yield increase in the system close to $7 \%$, above the $5 \%$ achieved with the current water heaters used in boilers to gas, as said earlier in this study.

The incoming water into the solar field is from ETA, because the system is more sensitive to the amount of particles and dispersed soil in the fluid. A buffer tank (TP) was used for heat exchange and recirculation of the solar field fluid (CS) with the feed water heater element (AAA), which is the mixing box between the water of the lung tank and the water from a river or other source of the explained above. After the heat has been exchanged in the feed water heater, the working fluid moves to the boiler (CD) so that it can be transformed into steam.

After the system simulations were carried out, it was verified that in order to achieve an average of $7 \%$ increase in the desired thermal efficiency, it would be necessary to use 50 plates of high pressure collector tubes of 30 tubes each of $2014 \mathrm{~W}$ thermal. The actual increment of this experiment was $7.4 \%$ yield (Table III). The composition of the water at the inlet of the feed water heater should be $43 \%$ flow from the slab system (CS) and 57\% from raw water collection, for mixing in the feed water heater (AAA).

Table IV - Result of the calculation of the modeling with the solar plates for an increase of approximately $7 \%$.

\begin{tabular}{|c|c|c|c|c|}
\hline QCS & Nboard & EFGV & $\begin{array}{c}\text { EFGV } \\
(\%)\end{array}$ & 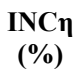 \\
\hline 99 & 49,16 & 0,2637 & 26,37 & 7,4 \\
\hline
\end{tabular}

QCS) Energy supplied by the set of plates in kW; Nboard) Number of plates calculated from the System; EFGV) Efficiency of the steam generator; INC.) Efficiency

For the purposes of the financial economic projection achieved with this system, considering the use of the solar energy system for boiler assistance in this scenario, for only 7 hours per day, applying the equation below, is obtained (2):

$$
E P V_{a}=\left(C T V_{h} x V_{t} \times h_{t} \times I N C_{\eta}\right) \times 365
$$

At where:

$E P V_{a}=$ Economy in annual steam production $(\mathrm{R} \$)$

$C T V_{h}=$ Cost of steam per hour worked

$V_{t}=$ Working Flow (Feedwater)

$h_{t}=$ daily hours of solar field work

$I N C_{\eta}=$ efficiency of the solar system

Using as parameters:

$C T V_{h}=\operatorname{USD} 11,15$ (given in table I)

$V_{t}=10 \mathrm{~m}^{3} / \mathrm{h}$

$h_{t}=7 \mathrm{~h}$

$I N C_{\eta}=7,4 \%$

Therefore:

$$
\begin{aligned}
E P V_{a}= & (44,64 \times 10 \times 7 \times 0,074) \times 365 \\
& E P V_{a}=U S D 21.081,30
\end{aligned}
$$

An annual saving of approximately USD 21.081,30 was achieved with the use of the solar-assisted steam generator system.

\section{Conclusion}

It is concluded that the efficiency varied by approximately $7.4 \%$, when the temperature of the feed water was increased by $20^{\circ} \mathrm{C}$, close to $48^{\circ} \mathrm{C}$. For this variation to occur, it was necessary to use 50 plates.

The technical feasibility of boiler economizer implementation to increase the efficiency and the production of heat in thermal generation systems of this kind is observed in this work. Other issues, for example economic financial viability, need to be adequately studied, considering the calculation for various types of fuels, with different values of calorific value, besides the costing of the implementation of this system in conjunction with the thermal machine, raising the economic feasibility analysis of the financial project.

New studies will be carried out in order to respond to these gaps, to contemplate the economic facet of this intervention.

However, in subsequent studies all the economic and environmental impacts resulting from this intervention must be taken into account, since many types of boilers use as fuel, non-renewable resources, which cause damage to the environment, causing greenhouse gases, among other adversities.

\section{References}

[1] ALFA LAVAL. Economizers. [s.d.]. Alfa Laval Aalborg Industries and Commerce. (2019). Available: 
http://www.aalborg-industries.com.br/general.php ?ix=23. Access in: fev 152019.

[2] F. A. Al-Sulaiman, "On the auxiliary boiler sizing assessment for solar driven supercritical $\mathrm{CO} 2$ double recompression Brayton cycles", Applied Energy, (2016), vol. 183, pp. 408-418.

[3] B. Buecker, "Basics of Boiler and HRSG Design", Oklahoma: Penn Well Corporation, (2002).

[4] B. Coelho, P. Schwarzbözl, A. Oliveira, and A. MENDES, "Biomass and central receiver system (CRS) hybridization: Volumetric air CRS and integration of a biomass waste direct burning boiler on steam cycle", Solar Energy, (2012), vol. 86, pp. 29122922,

[5] L. A. B. Cortez, E. E. S. Lora and E. O. Goméz, "Biomassa para energia", Campinas, São Paulo: Unicamp, (2008).

[6] K. S. Evaristo and R. S. Figueiredo, "Custo do vapor em agroindústria”, [SOBER. Sociedade Brasileira de Economia, Administração e Sociologia Rural]. Rio Branco, Acre, (2008). Available: http://www.sober. org.br/palestra/9/393.pdf. Access in: dez 152018.

[7] S. K. Guttikunda and P. Jawahar, "Atmospheric emissions and pollution from the coal-fired thermal power plants in India", Atmospheric Environment, (2014) vol. 92, pp. 449-460.
[8] G. P. Hammond and J. Spargo, "The prospects for coal-fired power plants with carbon capture and storage: A UK perspective", Energy Conversion and Management, (2014), vol. 86, pp. 476-489.

[9] E. S Lora, M. A. R. Nascimento, "Geração termoelétrica: planejamento, projeto e operação", Rio de Janeiro: Interciência, (2004).

[10] M. Zhang, C. Xu, X. Du, M. Amjad, D. Wen, “Offdesign performance of concentrated solar heat and coal double-source boiler power generation with thermocline energy storage", Applied Energy, (2017), vol.189, pp. 697-710.

[11] B. K. Hodgee. Sistemas e Aplicações de Energia Alternativa. Rio de Janeiro: LTC, (2011).

[12] BRASIL. Ministério de Minas e Energia. Análise da Inserção da Geração Solar na Matriz Elétrica Brasileira. Rio de Janeiro: EPE. (2012).

[13] L. B. Reis. Geração de Energia Elétrica. 2 ed. Barueri: Manole. (2016).

[14] E. B. Pereira, F. R. Martins, S. L. Abreu, and R. Ruther. Atlas brasileiro de energia solar . São José dos Campos : INPE, (2006).

[15] ARMATUREN. Custo de produção de vapor. (s.d.). Available: http://www.az-armaturen.com.br/. Access in: jun 152019. 